\title{
Pengaruh Substitusi Tepung Tapioka dan Tepung Terigu serta Lama Waktu Pengukusan terhadap Mutu Kerupuk Sape
}

Suburi Rahman', Afe Dwiani* ${ }^{1 *}$

${ }^{1}$ Program Studi Teknologi Hasil Pertanian, Fakultas Pertanian, Universitas Nahdlatul Wathan Mataram

\begin{tabular}{l}
\multicolumn{1}{c}{ ARTIKEL INFO } \\
\hline Sejarah artikel \\
Diterima $18 / 04 / 2021$ \\
Diterima dalam bentuk revisi 28/04/2021 \\
Diterima dan disetujui 24/05/2021 \\
Tersedia online 22/06/2021 \\
\hline Kata kunci \\
Kerupuk sape \\
Tepung terigu \\
Tepung tapioka \\
\hline
\end{tabular}

\begin{abstract}
ABSTRAK
Kerupuk sape merupakan salah satu jenis kerupuk khas daerah Kota Bima, Provinsi Nusa Tenggara Barat. Kerupuk ini menggunanakan tepung terigu sebagai bahan utama namun hingga saat ini kebutuhan terigu masih dipenuhi oleh impor. Untuk mengurangi konsumsi terigu diperlukan bahan baku lain seperti tepung tapioka. Selain bahan baku faktor lain yang mempengaruhi kualitas kerupuk adalah pengukusan. Karena itu diperlukan waktu pengukusan yang tepat agar kerupuk memiliki kualitas yang baik. Penelitian ini bertujuan untuk mengetahui pengaruh substitusi tepung tapioka, tepung terigu dan lama waktu pengukusan adonan terhadap mutu kerupuk sape. Penelitian ini menggunakan Rancangan Acak Lengkap (RAL) faktorial yaitu substitusi tepung tapioka dan tepung terigu serta lama pengukusan adonan yang terbagi menjadi 9 perlakuan yaitu: A1 (100 g : $0 \mathrm{~g}$ dan $1 \mathrm{jam}), \mathrm{A} 2$ (100 g : $0 \mathrm{~g}$ dan 1,5 jam), A3 (100 g : $0 \mathrm{~g}$ dan 2 jam), B1 (50 g : $50 \mathrm{~g}$ dan $1 \mathrm{jam}), \mathrm{B} 2$ (50 g : $50 \mathrm{~g}$ dan 1,5 jam), B3 (50 g : $50 \mathrm{~g}$ dan 2 jam), C1 (0 g : $100 \mathrm{~g}$ dan 1 jam), C2 (0 g : $100 \mathrm{~g}$ dan $1,5 \mathrm{jam})$ dan C3 (0 g : $100 \mathrm{~g}$ dan 2 jam). Hasil penelitian menunjukkan bahwa kerupuk sape yang dihasilkan telah memenuhi Standar Nasional Indonesia (SNI 0272:1991) untuk kadar air dan kadar lemak, sedangkan untuk kadar abu hanya kerupuk yang berbahan baku tepung tapioka saja yang memenuhi standar. Hasil penilaian mutu terbaik dalam penelitian ini adalah perlakuan A1 yaitu perlakuan tepung tapioka $100 \mathrm{~g}$ : tepung terigu $0 \mathrm{~g}$ dengan waktu pengukusan $1 \mathrm{jam}$.
\end{abstract}

C2021 Politeknik Pembangunan Pertanian Manokwari

*Email Penulis Korespondensi: dwiania@rocketmail.com suburirahman@yahoo.com ${ }^{1}$ 


\section{ABSTRACT}

Sape crackers are a type of cracker that comes from Bima City, West Nusa Tenggara Province. These crackers use wheat flour as the main ingredient, meanwhile, this flour is still imported from another country. To reduce wheat consumption, other raw materials are needed, such as cassava flour. Besides the raw material, another factor that affects the quality of crackers is the steaming process. Therefore, it takes the right time to steam the crackers to have good quality. This research aimed to determine the effect of substitution of tapioca flour, wheat flour, and time of steaming on the dough in the quality of sape crackers. The method that used in this study was a completely randomized design $(C R D)$ in factorial that are substitution of tapioca

\section{PENDAHULUAN}

Kerupuk merupakan suatu jenis makanan kecil yang sudah lama dikenal oleh sebagian besar masyarakat Indonesia. Kerupuk memiliki beragam bentuk, ukuran, warna, bau, rasa, kerenyahan, ketebalan, dan nilai gizi. Berdasarkan bahan-bahan tambahan yang digunakan untuk meningkatkan gizi dalam pengolahannya diketahui beberapa jenis kerupuk, yaitu kerupuk udang, kerupuk ikan, dan jenis lainnya. Sedangkan berdasarkan cara pengolahannya, rupa, dan bentuk kerupuk dikenal kerupuk mie, kerupuk kembang, dan lain sebagainya. Di samping itu, berdasarkan tempat atau daerah penghasilnya dikenal kerupuk Sidoarjo, kerupuk Surabaya dan kerupuk Palembang (Koswara, 2009). Kerupuk sape merupakan salah satu jenis kerupuk khas daerah Kecamatan Sape, Kabupaten Bima, Provinsi Nusa Tenggara Barat. flour, wheat flour and time of steaming which was divided into 9 treatments are $A 1((100 \mathrm{~g}: 0 \mathrm{~g}$ and 1 hour), A2 (100 $\mathrm{g}: 0 \mathrm{~g}$ and 1.5 hours), $\mathrm{A3}$ (100 $\mathrm{g}: 0$ $g$ and 2 hours), $B 1$ (50 g: $50 \mathrm{~g}$ and 1 hour), B2 (50 g: $50 \mathrm{~g}$ and 1.5 hours), $B 3$ (50 g: $50 \mathrm{~g}$ and 2 hours), C1 (0 g: $100 \mathrm{~g}$ and 1 hour), C2 ( $0 \mathrm{~g}: 100 \mathrm{~g}$ and 1.5 hours) and $C 3$ ( $0 \mathrm{~g}: 100 \mathrm{~g}$ and 2 hours). The result of sape crackers that have met the Indonesian national standard (SNI) for cracker products (0272:1991) is moisture and fat content. For the ash content, only crackers made from tapioca flour fulfilled SNI. The best quality in this study was the al treatment (100 g tapioca flour, $0 \mathrm{~g}$ wheat flour with 1 hour time of steaming).

Kerupuk sape sebagai makanan khas daerah Kota Bima selama ini masih belum terlalu dikenal luas. Oleh karena itu produk khas Kota Bima ini sangat penting untuk dikembangkan sebagai salah satu jenis aneka ragam makanan Nusantara. Pengembangan perlu diarahkan kepada pemanfaatan potensi sumberdaya alam lokal, peningkatan produktivitas tenaga kerja pedesaan terutama memperkuat ketahanan pangan berkelanjutan dan pemberdayaan ekonomi masyarakat (Marsigit, 2010).

Bahan baku utama pembuatan kerupuk sape adalah tepung terigu dan gandum merupakan bahan baku dalam pembuatan tepung terigu. Hingga saat ini Indonesia masih memenuhi kebutuhan tepung terigu dengan cara impor. Volume impor gandum dari tahun ketahun juga semakin meningkat. Berdasarkan data APTINDO (2013), Indonesia mengimpor gandum terbanyak dari Australia (70,7\%), 
Kanada (14,9\%), dan Amerika Serikat (11\%). Salah satu upaya yang telah dilakukan untuk mengurangi penggunaan tepung terigu adalah melalui subtitusi tepung pangan lokal. Tepung pangan lokal yang dimaksudkan adalah tepung umbiumbian. Umbi-umbian yang ada di Indonesia sangat melimpah, sehingga mempunyai potensi besar untuk dikembangkan, diantaranya adalah ubi kayu sebagai bahan baku tepung tapioka.

Tepung tapioka banyak
dimanfaatkan sebagai bahan dalam pembuatan kerupuk seperti kerupuk keong (Anam, 2005), kerupuk seledri (Kusuma, 2013), kerupuk terubuk (Chaniago, 2019) dan sebagainya. Kualitas kerupuk dipengaruhi dari bahan utama yang digunakan. Tapioka memiliki kandungan utama pati yang akan mempengaruhi proses gelatinisasi. Semakin tinggi pati pada adonan maka semakin tinggi pengembangan produk (Mulyana, et al., 2014). Selain itu, kerupuk yang terbuat dari tepung tapioka akan mempengaruhi tekstur kerupuk menjadi lebih renyah (Despita et al., 2015).

Selain bahan baku tepung, proses pengolahan kerupuk sangat menentukan kualitas produk yang dihasilkan. Salah satu proses pengolahan kerupuk yang mempengaruhi kualitas kerupuk adalah proses pengukusan. Pengukusan sering diartikan sebagai pemasakan yang dilakukan melalui media uap panas dengan suhu pemanasan sekitar $100^{\circ} \mathrm{C}$ selama 15 menit (Rosiani et al., 2015).

Berdasarkan uraian di atas maka telah dilakukan penelitian mengenai pengaruh substitusi tepung terigu dan tepung tapioka serta lama waktu pengukusan terhadap mutu kerupuk sape. Penelitian ini bertujuan untuk mengetahui pengaruh substitusi tepung tapioka, tepung terigu dan waktu pengukusan dalam pembuatan kerupuk sape agar dapat diterima dan dikenal luas oleh masyarakat.

\section{METODE}

Proses pembuatan kerupuk sape adalah dengan cara mempersiapkan bahan baku (tepung tapioka dan tepung terigu) dan bahan tambahan (air, soda kue, garam, penyedap dan minyak untuk menggoreng produk). Semua bahan ditimbang sesuai kebutuhan. Bahan baku (tapioka dan terigu sesuai perlakuan) dicampur dengan soda kue, ditambahkan air, diaduk hingga rata dan mengembang. Kemudian ditambahkan garam dan penyedap, diaduk rata serta diamkan selama 15 menit. Adonan dimasukkan dalam cetakan yang telah diolesi dengan minyak agar tidak lengket kemudian adonan dikukus (suhu $80^{\circ} \mathrm{C}$ ) sesuai perlakuan. Setelah itu, adonan dikeluarkan dan didinginkan kemudian dipotong menggunakan senar gitar dengan ketebalan 0,2 mm. Kerupuk basah 
dikeringkan dengan tampah menggunakan sinar matahari selama 3 hari (mulai jam 09.00-16.30 WITA). Kerupuk yang telah kering digoreng (suhu $160^{\circ} \mathrm{C}$ ) menggunakan minyak hingga matang dan ditiriskan kemudian dikemas dan disimpan untuk dianalisis lebih lanjut.

Alat yang digunakan dalam penelitian ini terdiri dari 3 tahap antara lain untuk pembuatan kerupuk: panci, dandang, cetakan kayu, senar gitar, kompor gas, sendok, ember plastik, baskom, mangkok, dandang dan timbangan digital; untuk analisa kimia dan fisik: botol timbang, desikator, oven, timbangan analitik, cawan abu, tanur, labu soxhlet, kertas saring, pensil dan penggaris serta untuk organoleptik: air mineral, mangkok, kuesioner dan pulpen. Bahan yang digunakan dalam penelitian ini adalah tepung terigu, tepung tapioka, penyedap, garam, soda kue, minyak goreng, dan air.

Penelitian ini menggunakan Rancangan Acak Lengkap (RAL) faktorial, yaitu substitusi tepung terigu dan tepung tapioka dan lama pengukusan adonan yang terbagi menjadi 9 perlakuan, yaitu perbandingan tepung tapioka: tepung terigu dan waktu pengukusan seperti berikut ini : A1 (100 g : $0 \mathrm{~g}$ dan $1 \mathrm{jam})$, A2 (100 g : $0 \mathrm{~g}$ dan 1,5 jam), A3 (100 g : $0 \mathrm{~g}$ dan 2 jam), B1 (50 g : $50 \mathrm{~g}$ dan $1 \mathrm{jam}), \mathrm{B} 2$ (50 g : $50 \mathrm{~g}$ dan 1,5 jam), B3 (50 g : $50 \mathrm{~g}$ dan 2 jam), C1 (0 $\mathrm{g}: 100 \mathrm{~g}$ dan 1 jam), C2 (0 g : $100 \mathrm{~g}$ dan 1,5 jam) dan C3 (0 g : $100 \mathrm{~g}$ dan 2 jam).

Data hasil pengamatan di analisis dengan analisa keragaman (Analysis of Variance) pada taraf nyata $5 \%$ dengan menggunakan software SPSS 16.0. Apabila terdapat beda nyata, dilakukan uji lanjut menggunakan uji Beda Nyata Jujur (BNJ) pada taraf yang sama (Hanafiah, 2002). Parameter yang dianalisa adalah sifat kimia: kadar air dan abu (Sudarmadji et al., 2007), kadar lemak (AOAC, 1995); sifat fisik: volume pengembangan (Koswara, 2009) dan organoleptik: uji hedonik (Rahayu, 1998).

\section{HASIL DAN PEMBAHASAN}

\section{Kadar Air}

Analisa kadar air kerupuk Sape mentah setelah pengeringan berkisar antara $2,62-3,80 \%$. Pengaruh substitusi tepung tapioka dan terigu serta lama waktu pengukusan menyebabkan perbedaan kadar air yang signifikan pada kerupuk Sape yang dihasilkan seperti terlihat pada Tabel 1 .

Tabel 1. Pengaruh Perlakuan Substitusi Tepung Tapioka, Tepung Terigu dan Lama Pengukusan Terhadap Kadar Air Kerupuk Sape

\begin{tabular}{cc}
\hline Perlakuan & Kadar air(\%) \\
\hline Kontrol & $2,72^{\mathrm{a}}$ \\
A1 & $2,77^{\mathrm{a}}$ \\
A2 & $2,62^{\mathrm{a}}$ \\
A3 & $2,74^{\mathrm{a}}$ \\
B1 & $3,2^{\mathrm{b}}$ \\
B2 & $3,28^{\mathrm{b}}$ \\
B3 & $3,55^{\mathrm{bc}}$ \\
C1 & $3,47^{\mathrm{bc}}$ \\
C2 & $3,73^{\mathrm{c}}$ \\
C3 & $3,8^{\mathrm{c}}$ \\
\hline
\end{tabular}


Berdasarkan Tabel 1 dapat diketahui bahwa terdapat perbedaan yang signifikan $(\mathrm{P}<0,05)$ antar perlakuan dalam pembuatan kerupuk sape terhadap hasil analisa kadar air. Pengukuran kadar air kerupuk sape setelah pengeringan untuk semua perlakuan telah memenuhi kontrol minimum kadar air kerupuk.

Standar kadar air untuk kerupuk adalah maksimal $12 \%$ berdasarkan (SNI 0272:1991). Kadar air terendah terdapat pada perlakuan A2 (tepung tapioka $100 \mathrm{~g}$ : tepung terigu $0 \mathrm{~g}$ dan waktu pengukusan 1,5 jam) sebesar 2,62\% dan kadar air tertinggi pada perlakuan C3 (tepung tapioka $0 \mathrm{~g}$ : tepung terigu $100 \mathrm{~g}$ dan waktu pengukusan 2 jam) sebesar 3,80\%.

Semakin rendah penambahan tepung tapioka dan semakin tinggi penambahan tepung terigu maka kadar air yang dihasilkan semakin tinggi. Hal ini disebabkan kadar pati tepung tapioka lebih rendah dari tepung terigu. Kadar air erat kaitannya dengan kadar pati.

Menurut Winarno

karbohidrat (pati) adalah salah satu komponen penting dalam menentukan besarnya nilai daya serap air. Pati merupakan senyawa yang bersifat hidrofilik. Granula pati memiliki kemampuan menyerap air yang sangat besar karena jumlah gugus hidroksil pati yang sangat besar, oleh karena itu semakin tinggi pati maka kadar airnya semakin kecil.
Hasil penelitian ini menunjukkan persamaan dengan hasil penelitian Kusuma et al. (2013), dimana dikatakan bahwa semakin tinggi penggunaan tepung terigu akan meningkatkan kadar air kerupuk seledri yang dihasilkan.

\section{Kadar Abu}

Analisa kadar abu kerupuk Sape mentah setelah pengeringan berkisar antara 0,49\%-2,61\%. Pengaruh substitusi tepung tapioka dan terigu serta lama waktu pengukusan menyebabkan perbedaan kadar abu yang signifikan pada kerupuk sape yang dihasilkan seperti terlihat pada Tabel 2.

Tabel 2. Pengaruh Perlakuan Substitusi Tepung Tapioka, Tepung Terigu dan Lama Pengukusan terhadap Kadar Abu Kerupuk Sape

\begin{tabular}{cc}
\hline Perlakuan & Kadar abu(\%) \\
\hline Kontrol & $2,61^{\mathrm{e}}$ \\
A1 & $0,49^{\mathrm{a}}$ \\
A2 & $0,93^{\mathrm{abc}}$ \\
A3 & $0,79^{\mathrm{ab}}$ \\
B1 & $1,09^{\mathrm{abcd}}$ \\
B2 & $1,51^{\mathrm{cd}}$ \\
B3 & $1,41^{\mathrm{bcd}}$ \\
C1 & $1,41^{\mathrm{bcd}}$ \\
C2 & $1,64^{\mathrm{d}}$ \\
C3 & $1,67^{\mathrm{d}}$ \\
\hline
\end{tabular}

Berdasarkan Tabel 2 dapat diketahui bahwa terdapat perbedaan yang signifikan $(\mathrm{P}<0,05)$ antar perlakuan dalam pembuatan kerupuk sape terhadap hasil analisa kadar abu. Kadar abu untuk kerupuk adalah maksimal $1 \%$ berdasarkan SNI 0272:1991. Pengukuran kadar abu kerupuk sape mentah setelah pengeringan untuk 
perlakuan A1 (tepung tapioka $100 \mathrm{~g}$ : tepung terigu $0 \mathrm{~g}$ dan waktu pengukusan 1 jam), A2 (tepung tapioka $100 \mathrm{~g}$ : tepung terigu $0 \mathrm{~g}$ dan waktu pengukusan $1,5 \mathrm{jam}$ ) dan A3 (tepung tapioka $100 \mathrm{~g}$ : tepung terigu $0 \mathrm{~g}$ dan waktu pengukusan 2 jam) telah memenuhi kadar abu kerupuk, namun untuk perlakuan yang lain belum memenuhi kadar abu termasuk juga kerupuk yang digunakan sebagai kontrol. Kadar abu terendah terdapat pada perlakuan A1 (tepung tapioka $100 \mathrm{~g}$ : tepung terigu $0 \mathrm{~g}$ dan waktu pengukusan 1 jam) sebesar 0,49\% dan kadar abu tertinggi pada kontrol sebesar $2,61 \%$.

Hal ini disebabkan karena perbandingan kadar abu tepung tapioka lebih rendah dibandingkan tepung terigu. Rendahnya kadar abu kerupuk mentah dengan bahan baku tepung tapioka juga dihasilkan dari beberapa penelitian seperti pada produk kerupuk daging keong mas (Anam, 2005), kerupuk lidah buaya (Rosiani et al., 2015) dan kerupuk jamur tiram (Fibra et al., 2015).

\section{Kadar Lemak}

Analisa kadar lemak kerupuk Sape mentah setelah pengeringan berkisar antara $0,51-0,70 \%$. Pengaruh substitusi tepung tapioka dan tepung terigu serta lama waktu pengukusan menyebabkan perbedaan kadar lemak yang signifikan pada kerupuk Sape mentah yang dihasilkan seperti terlihat pada Tabel 3.

Tabel 3. Pengaruh Perlakuan Substitusi Tepung Tapioka, Tepung Terigu dan Lama Pengukusan Terhadap Kadar Lemak Kerupuk Sape

\begin{tabular}{cc}
\hline Perlakuan & Kadar lemak $(\%)$ \\
\hline Kontrol & $0,7^{\mathrm{abc}}$ \\
A1 & $0,54^{\mathrm{a}}$ \\
A2 & $0,56^{\mathrm{ab}}$ \\
A3 & $0,51^{\mathrm{a}}$ \\
B1 & $0,6^{\mathrm{abc}}$ \\
B2 & $0,58^{\mathrm{abc}}$ \\
B3 & $0,57^{\mathrm{ab}}$ \\
C1 & $0,69^{\mathrm{c}}$ \\
C2 & $0,65^{\mathrm{bc}}$ \\
C3 & $0,63^{\mathrm{abc}}$ \\
\hline
\end{tabular}

Berdasarkan Tabel 3 dapat diketahui bahwa terdapat perbedaan yang signifikan $(\mathrm{P}<0,05)$ antar perlakuan dalam pembuatan kerupuk Sape terhadap hasil analisa kadar lemak. Kadar lemak terendah terdapat pada perlakuan A3 (tepung tapioka $100 \mathrm{~g}$ : tepung terigu $0 \mathrm{~g}$ dan waktu pengukusan 2 jam) sebesar $0,51 \%$ dan kadar lemak tertinggi pada kontrol sebesar $0,70 \%$.

Hal ini disebabkan oleh kadar lemak tepung tapioka lebih rendah dari tepung terigu. Selain itu pengaruh waktu perebusan juga mempengaruhi perbedaan kadar lemak kerupuk dimana semakin lama waktu pengukusan kadar lemak kerupuk akan semakin kecil, hal ini disebabkan karena pemanasan yang lama mengakibatkan lemak mengalami oksidasi sehingga akan menguap. Menurut Sundari et al. (2015) tingkat kerusakan lemak sangat bervariasi 
tergantung pada suhu yang digunakan lamanya waktu proses pengolahan. Makin tinggi suhu yang digunakan, maka semakin intens kerusakan lemak.

\section{Volume Pengembangan}

Volume pengembangan kerupuk Sape berkisar antara 6,2-10,5 cm. Pengaruh substitusi tepung tapioka dan tepung terigu serta lama waktu pengukusan menyebabkan perbedaan volume pengembangan yang signifikan pada kerupuk sape yang dihasilkan seperti terlihat pada Tabel 4.

Tabel 4. Pengaruh Perlakuan Substitusi Tepung Tapioka, Tepung Terigu dan Lama Pengukusan terhadap Volume Pengembangan Kerupuk Sape

\begin{tabular}{cc}
\hline Perlakuan & $\begin{array}{c}\text { Volume } \\
\text { Pengembangan }(\mathrm{cm})\end{array}$ \\
\hline Kontrol & $6,5^{\mathrm{abc}}$ \\
A1 & $10,5^{\mathrm{d}}$ \\
A2 & $10,4^{\mathrm{d}}$ \\
A3 & $10,3^{\mathrm{d}}$ \\
B1 & $8,2^{\mathrm{bc}}$ \\
B2 & $8,1^{\mathrm{c}}$ \\
B3 & $7,8^{\mathrm{abc}}$ \\
C1 & $6,3^{\mathrm{abc}}$ \\
C2 & $6,5^{\mathrm{ab}}$ \\
C3 & $6,2^{\mathrm{a}}$ \\
\hline
\end{tabular}

Berdasarkan Tabel 4 dapat diketahui bahwa terdapat perbedaan yang signifikan $(\mathrm{P}<0,05)$ antar perlakuan dalam pembuatan kerupuk Sape terhadap uji fisik volume pengembangan. Volume pengembangan kerupuk tertinggi terdapat pada perlakuan A1 (tepung tapioka $100 \mathrm{~g}$ : tepung terigu $0 \mathrm{~g}$ dan waktu pengukusan 1 jam) sebesar 10,5 $\mathrm{cm}$ dan volume pengembangan terendah pada perlakuan $\mathrm{C} 3$ (tepung tapioka $0 \mathrm{~g}$ : tepung terigu $100 \mathrm{~g}$ dan waktu pengukusan 2 jam) sebesar 6,2 $\mathrm{cm}$.

Perbedaan volume pengembangan ini disebabkan karena perbedaan bahan baku utama pada produk kerupuk. Hal ini dikarenakan daya kembang kerupuk sangat berkaitan dengan pati yang ada dalam produk. Pati akan mengalami gelatinisasi karena suhu dan menghasilkan rongga udara pada kerupuk yang digoreng (Mulyana, et al., 2014).).

\section{Rasa}

Hasil uji organoleptik rasa kerupuk sape setelah digoreng berkisar antara 2,70 (agak disukai) - 3,85 (disukai). Pengaruh substitusi tepung tapioka dan tepung terigu serta lama waktu pengukusan menyebabkan perbedaan yang signifikan pada rasa kerupuk sape yang dihasilkan seperti terlihat pada Tabel 5.

Tabel 5. Pengaruh Perlakuan Substitusi Tepung Tapioka, Tepung Terigu dan Lama Pengukusan Terhadap Rasa (Hedonik) Kerupuk Sape

\begin{tabular}{cc}
\hline Perlakuan & Rasa (Hedonik) \\
\hline Kontrol & $3,85^{\mathrm{c}}$ \\
A1 & $3,85^{\mathrm{c}}$ \\
A2 & $3,8^{\mathrm{c}}$ \\
A3 & $3,8^{\mathrm{c}}$ \\
B1 & $2,85^{\mathrm{ab}}$ \\
B2 & $2,7^{\mathrm{a}}$ \\
B3 & $2,9^{\mathrm{ab}}$ \\
C1 & $3,85^{\mathrm{c}}$ \\
C2 & $3,7^{\mathrm{bc}}$ \\
C3 & $3,8^{\mathrm{c}}$ \\
\hline
\end{tabular}


Berdasarkan Tabel 5 dapat diketahui bahwa terdapat perbedaan yang signifikan $(\mathrm{P}<0,05)$ antar perlakuan dalam pembuatan kerupuk Sape terhadap uji organoleptik rasa kerupuk setelah digoreng.

Perlakuan penggunaan tepung tapioka tanpa tepung terigu (A1, A2 dan A3) dan sebaliknya perlakuan tepung terigu tanpa tepung tapioka $(\mathrm{C} 1, \mathrm{C} 2$ dan $\mathrm{C} 3)$ tidak berbeda nyata dengan perlakuan kontrol maupun antar perlakuan tersebut dimana panelis menyukai kerupuk dengan masingmasing perlakuan tersebut.

Panelis memberikan skor nilai organoleptik rasa yang sama pada kerupuk dengan perlakuan bahan baku tepung terigu saja maupun tepung tapioka saja, namun skor berbeda pada perlakuan kombinasi tepung terigu dan tepung tapioka. Nilai skor uji organoleptik rasa kerupuk tertinggi dihasilkan perlakuan kontrol dan A1 (tepung tapioka $100 \mathrm{~g}$ : tepung terigu $0 \mathrm{~g}$ dan waktu pengukusan 1 jam) sebesar 3,85 (disukai) dan skor rasa terendah dihasilkan perlakuan B2 (tepung tapioka $50 \mathrm{~g}$ : tepung terigu $50 \mathrm{~g}$ dan waktu pengukusan 1,5 jam) sebesar 2,70 (agak disukai). Perlakuan kombinasi antara penggunaan tepung terigu dan tepung tapioka (B1, B2 dan B3) terhadap nilai rasa kerupuk memiliki skor rendah.

Kerupuk sape yang dihasilkan dengan kombinasi tepung terigu dan tepung tapioka berasa agak tawar atau tidak terasa penggunaan bumbu seperti garam yang menguatkan rasa sementara perlakuan yang lain memiliki rasa sedikit asin. Hal ini mengindikasikan bahwa penggunaan bumbu seperti garam dengan konsentrasi yang sama pada setiap perlakuan tidak mempengaruhi adonan kerupuk Sape kombinasi tepung terigu dan tapioka.

Menurut Chaniago et al. (2019) rasa yang ditimbulkan pada kerupuk dipengaruhi oleh komposisi bumbu yang dicampurkan pada saat pengolahan kerupuk. Penilaian panelis ini dapat disimpulkan bahwa komposisi penggunaan bumbu seperti garam mempengaruhi citarasa kerupuk yang dihasilkan.

\section{Aroma}

Hasil uji organoleptik aroma kerupuk Sape setelah digoreng berkisar antara 2,50 (agak disukai) - 3,55 (disukai). Pengaruh substitusi tepung tapioka dan tepung terigu serta lama waktu pengukusan menyebabkan perbedaan yang signifikan pada aroma kerupuk Sape yang dihasilkan seperti terlihat pada Tabel 6 .

Tabel 6. Pengaruh Perlakuan Substitusi Tepung Tapioka, Tepung Terigu dan Lama Pengukusan terhadap Aroma (Hedonik) Kerupuk Sape

\begin{tabular}{cc}
\hline Perlakuan & Aroma $($ Hedo \\
\hline Kontrol & $3,45^{\mathrm{cd}}$ \\
A1 & $3,35^{\text {bcd }}$ \\
A2 & $3,4^{\text {bcd }}$ \\
A3 & $3,45^{\mathrm{cd}}$ \\
B1 & $2,65^{\mathrm{ab}}$ \\
B2 & $2,7^{\mathrm{abc}}$
\end{tabular}




\begin{tabular}{cc} 
B3 & $2,5^{\mathrm{a}}$ \\
$\mathrm{C} 1$ & $3,5^{\mathrm{d}}$ \\
$\mathrm{C} 2$ & $3,55^{\mathrm{d}}$ \\
$\mathrm{C} 3$ & $3,35^{\text {bcd }}$ \\
\hline
\end{tabular}

Berdasarkan Tabel 6 dapat diketahui bahwa terdapat perbedaan yang signifikan $(\mathrm{P}<0,05)$ antar perlakuan dalam pembuatan kerupuk Sape terhadap uji organoleptik aroma kerupuk setelah digoreng. Nilai skor uji organoleptik aroma kerupuk tertinggi dihasilkan perlakuan C2 (tepung tapioka $0 \mathrm{~g}$ : tepung terigu $100 \mathrm{~g}$ dan waktu pengukusan 1,5 jam) sebesar 3,55 (disukai) dan skor rasa terendah dihasilkan perlakuan B3 (tepung tapioka 50 $\mathrm{g}$ : tepung terigu $50 \mathrm{~g}$ dan waktu pengukusan 2 jam) sebesar 2,50 (agak disukai). Aroma khas tapioka pada perlakuan A1, A2 dan A3 dan aroma khas terigu pada perlakuan $\mathrm{C} 1, \mathrm{C} 2$ dan $\mathrm{C} 3$ disukai oleh panelis, sementara perlakuan dengan kombinasi terigu dan tapioka menghasilkan aroma yang kurang disukai oleh panelis.

Hal ini dapat disebabkan oleh pencampuran kedua tepung tersebut setelah mengalami proses pengolahan menghasilkan aroma yang kurang khas karena terjadinya interaksi dari senyawa pada kedua bahan tersebut yang menghasilkan aroma kurang disukai oleh panelis jika dibandingkan dengan kerupuk yang hanya menggunakan tepung terigu atau tepung tapioka saja.
Menurut Chaniago et al. (2019) adanya interaksi alami antara komponen aroma dan komponen nutrisi dalam makan seperti karbohidrat, protein dan lemak serta penerimaan konsumen yang sangat relatif, sehingga akan berpengaruh terhadap respon yang diberikan oleh panelis dalam menilai aroma kerupuk.

\section{Tekstur}

Hasil uji organoleptik tekstur kerupuk Sape setelah digoreng berkisar antara 3,50 - 3,95 (suka). Pengaruh substitusi tepung tapioka dan tepung terigu serta lama waktu pengukusan menyebabkan perbedaan yang signifikan pada tekstur kerupuk Sape yang dihasilkan seperti terlihat pada Tabel 7.

Tabel 7. Pengaruh Perlakuan Substitusi Tepung Tapioka, Tepung Terigu dan Lama Pengukusan terhadap Tekstur (Hedonik) Kerupuk Sape

\begin{tabular}{|c|c|}
\hline Perlakuan & Tekstur (Hedonik) \\
\hline Kontrol & $3,95^{\mathrm{a}}$ \\
\hline A1 & $3,95^{\mathrm{a}}$ \\
\hline $\mathrm{A} 2$ & $3,9^{\mathrm{a}}$ \\
\hline A3 & $3,7^{\mathrm{a}}$ \\
\hline B1 & $3,55^{\mathrm{a}}$ \\
\hline B2 & $3,55^{\mathrm{a}}$ \\
\hline B3 & $3,5^{\mathrm{a}}$ \\
\hline $\mathrm{C} 1$ & $3,65^{\mathrm{a}}$ \\
\hline $\mathrm{C} 2$ & $3,7^{\mathrm{a}}$ \\
\hline $\mathrm{C} 3$ & $3,65^{\mathrm{a}}$ \\
\hline
\end{tabular}

diketahui bahwa tidak terdapat perbedaan yang signifikan $(\mathrm{P}<0,05)$ antar perlakuan dalam pembuatan kerupuk sape terhadap uji organoleptik tekstur kerupuk Sape setelah digoreng. Nilai skor uji organoleptik tekstur 
kerupuk tertinggi pada perlakuan kontrol dan A1 (tepung tapioka $100 \mathrm{~g}$ : tepung terigu $0 \mathrm{~g}$ dan waktu pengukusan 1 jam) sebesar 3,95 (disukai) dan skor rasa terendah pada perlakuan B3 (tepung tapioka $50 \mathrm{~g}$ : tepung terigu $50 \mathrm{~g}$ dan waktu pengukusan 2 jam) sebesar 3,50 (disukai). Panelis memberikan penilaian yang sama terhadap tekstur kerupuk Sape pada semua perlakuan.

Salah satu hal yang menjadi tolak ukur kesukaan masyarakat dari produk kerupuk, yaitu dari segi tekstur, dimana tekstur tersebut dipengaruhi oleh adanya kandungan pati dan kadar air bahan pada kerupuk serta ketebalan dari kerupuk tersebut. Jika diamati secara organoleptik, kerupuk yang disukai oleh konsumen yaitu kerupuk renyah dan kriuk saat dikonsumsi (Irmayanti et al., 2017). Tekstur yang renyah merupakan karakteristik kesukaan konsumen terhadap kerupuk sementara tekstur yang keras tidak disukai konsumen. Kerupuk Sape memiliki kriteria disukai oleh panelis.

\section{Warna}

Hasil uji organoleptik warna kerupuk Sape setelah digoreng berkisar antara 2,80 (agak disukai) - 3,65 (disukai). Pengaruh substitusi tepung tapioka dan tepung terigu serta lama waktu pengukusan menyebabkan perbedaan yang signifikan pada warna kerupuk sape yang dihasilkan seperti terlihat pada Tabel 8.
Tabel 8. Pengaruh Perlakuan Substitusi Tepung Tapioka, Tepung Terigu dan Lama Pengukusan terhadap Warna (Hedonik) Kerupuk Sape

\begin{tabular}{cc}
\hline Perlakuan & Warna (Hedonik) \\
\hline Kontrol & $3,65^{\mathrm{d}}$ \\
A1 & $3,65^{\mathrm{d}}$ \\
A2 & $3,6^{\mathrm{cd}}$ \\
A3 & $3,55^{\mathrm{bcd}}$ \\
B1 & $2,8^{\mathrm{a}}$ \\
B2 & $2,8^{\mathrm{a}}$ \\
B3 & $2,85^{\mathrm{a}}$ \\
C1 & $2,95^{\mathrm{abc}}$ \\
C2 & $2,9^{\mathrm{ab}}$ \\
C3 & $2,9^{\mathrm{ab}}$ \\
\hline
\end{tabular}

Berdasarkan Tabel 8 diketahui bahwa terdapat perbedaan yang signifikan $(\mathrm{P}<0,05)$ antar perlakuan dalam pembuatan kerupuk sape terhadap uji organoleptik warna kerupuk setelah digoreng. Nilai skor uji organoleptik warna kerupuk tertinggi dihasilkan perlakuan control dan A1 (tepung tapioka $100 \mathrm{~g}$ : tepung terigu $0 \mathrm{~g}$ dan waktu pengukusan 1 jam) dihasilkan perlakuan sebesar 3,65 (disukai) dan skor rasa terendah dihasilkan perlakuan B2 (tepung tapioka $50 \mathrm{~g}$ : tepung terigu $50 \mathrm{~g}$ dan waktu pengukusan 1,5 jam) dan B3 (tepung tapioka $50 \mathrm{~g}$ : tepung terigu $50 \mathrm{~g}$ dan waktu pengukusan 2 jam) sebesar 2,80 (agak disukai). Panelis lebih menyukai warna kerupuk berbahan baku tapioka (A1, A2 dan A3) yang memiliki nilai sama dengan kerupuk kontrol dibandingkan dengan kerupuk dari terigu $(\mathrm{C} 1, \mathrm{C} 2, \mathrm{C} 3)$ atau kombinasi terigu dan tapioka (B1, B2, B3). 
Kerupuk Sape yang disukai panelis adalah kerupuk yang berwarna kuning agak putih sementara warna kerupuk yang agak gelap kurang disukai oleh panelis. Perbedaan warna pada kerupuk Sape dapat disebabkan oleh perbedaan bahan baku dan lama waktu pengukusan dimana kerupuk yang berbahan baku tapioka lebih memiliki warna yang lebih cerah yaitu putih kekuningan sementara kerupuk yang berbahan kombinasi tapioka dan terigu atau kerupuk yang hanya menggunakan terigu warnanya putih gelap agak sedikit coklat.

Menurut Winarno (2004), warna dalam bahan dapat berasal dari pigmen alami bahan pangan itu sendiri, reaksi karamelisasi, reaksi Maillard, reaksi senyawa organik dengan udara, dan penambahan zat warna baik alami maupun sintetik. Dapat disimpulkan bahwa kerupuk yang berbahan baku terigu atau kombinasi dengan tapioka mengalami reaksi karamelisasi atau reaksi Mailard dari tepung terigu sehingga membuat warna kerupuk menjadi lebih gelap jika dibandingkan dengan yang hanya berbahan tapioka. Lebih lanjut hasil penelitian Nurul et al. (2009) mengatakan bahwa nilai kecerahan kerupuk mengalami penurunan akibat penambahan tepung tapioka pada kerupuk ikan.

\section{KESIMPULAN DAN SARAN}

Substitusi tepung tapioka dan tepung terigu serta lama waktu pengukusan memberikan pengaruh terhadap mutu kimia, fisik dan organoleptik pada kerupuk Sape; Produk kerupuk Sape yang dihasilkan telah memenuhi Standar Nasional Indonesia (SNI 0272:1991) produk kerupuk untuk kadar air dan lemak sedangkan untuk kadar abu hanya kerupuk yang berbahan baku tepung tapioka saja yang memenuhi standar; dan hasil rata-rata penilaian mutu terbaik dalam penelitian ini adalah perlakuan A1 yaitu tepung tapioka $100 \mathrm{~g}$ : tepung terigu $0 \mathrm{~g}$ dan waktu pengukusan 1 jam.

\section{DAFTAR PUSTAKA}

AOAC. (1995). Official methods of analysis of the association of official analytical chemist, $16 \mathrm{rd}$ edition. Publisher AOAC, I W. Gmc: Washington.

Anam, C. (2005). Penggunaan daging keong mas (Pomacea caniculata) terhadap kualitas kerupuk. Caraka Tani, 20 (2), 80-83. DOI: https://doi.org/10.20961/carakatani. v20i2.20502

Asosiasi Produsen Tepung Terigu Indonesia (APTINDO). (2016, Oktober 28). Indonesia wheat flour consumption and growth. Diakses dari

http://aptindo.or.id/2016/10/28/indo nesia-wheat-flour-cunsumptiongrowth/.

Chaniago, R., Lamusu D., \& Samaduri L. (2019). Kombinasi tepung terigu dan tepung tapioka terhadap daya 
kembang dan sifat organoleptik kerupuk terubuk (Saccharum edule Hasskarl). Jurnal Pengolahan Pangan, 4 (1), 1-8. Diakses dari https://pengolahanpangan.jurnalpert anianunisapalu.com/index.php/pang an/article/view/20/18

Despita, R., Yuliasih S., \& Rahmi A. (2015). Pengaruh penambahan tepung tapioka terhadap warna, kerenyahan, dan rasa kerupuk ampas susu kedelai. Prosiding Seminar Hasil Penelitian Tanaman Aneka Kacang dan Umbi. Diakses dari

https://balitkabi.litbang.pertanian.g o.id/wp-

content/uploads/2016/06/45_rika\% 20despita.pdf.

Fibra, N., Sugiharto R., \& D.W. Sari. (2015). Pengaruh perbandingan tepung tapioka dan tepung jamur tiram putih (Pleurotus Oestreatus) terhadap volume pengembangan, kadar protein dan organoleptik kerupuk. Jurnal Teknologi Industri dan Hasil Pertanian, 20 (1), 11-24. Diakses dari. jurnal.fp.unila.ac.id/index.php/JTH P/article/download/1401/1287.

Hanafiah, K.A. (2002). Rancangan percobaan: teori dan aplikasi. Jakarta: PT. Raja Grafindo Permata.

Irmayanti, Syam, H., \& Jamaluddin. (2017). Perubahan tekstur kerupuk berpati akibat suhu dan lama penyangraian. Jurnal Pendidikan Teknologi Pertanian, 3, S165-S174. DOI:https://doi.org/10.26858/jptp.v $3 \mathrm{i} 0.5716$

Koswara, S. (2009). Pengolahan aneka kerupuk. Diakses dari https://www.google.com/url?sa=t\& $\mathrm{rct}=\mathrm{j} \& \mathrm{q}=\&$ esrc $=\mathrm{s} \&$ source $=$ web $\& \mathrm{~cd}$ $=\& \mathrm{cad}=\mathrm{rja} \& u a c t=8 \& \mathrm{ved}=2 \mathrm{ahUKE}$ wjr8ajXiZvwAhXD5nMBHRkdAz 8QFjAAegQIAxAD\&url=http\%3A $\% 2 \mathrm{~F} \% 2 \mathrm{Ftekpan}$.unimus.ac.id $\% 2 \mathrm{Fw}$ pcontent $\% 2$ Fuploads $\% 2 F 2013 \% 2 \mathrm{~F}$ 07\%2FPENGOLAHAN-ANEKA-

K-E-R-U-P-U-

K.pdf\&usg=AOvVaw3K9T-YGFt$x$ Vr7IADYv8Eu.

Kusuma, T.D., Suseno, T.I.P., \& Surjoseputro, S. (2013). Pengaruh proporsi tapioka dan terigu terhadap sifat fisikokimia dan organoleptik kerupuk berseledri. Jurnal Teknologi Pangan, 12 (1), 17-28. Diakses dari https://media.neliti.com/media/publ ications/232322-pengaruh-proporsitapioka-dan-terigu-ter8c1f2f77.pdf.

Marsigit, W. (2010). Pengembangan produk diversifikasi pangan olahan lokal Bengkulu untuk menunjang ketahanan pangan berkelanjutan. AGRITECH, 3 (4), 256-264. Diakses dari https://jurnal.ugm.ac.id/agritech/arti cle/download/9717/7293.

Mulayana, Susanto W.H., \& I. Purwantiningrum. (2014). Pengaruh proporsi (tepung tempe semangit : tepung tapioka) dan penambahan air terhadap karakteristik kerupuk tempe semangit. Jurnal Pangan dan Agroindustri, 2 (4), 113-120. Diakses dari https://jpa.ub.ac.id/index.php/jpa/ar ticle/download/83/100.

Nurul, H., Boni, I., \& Noryati, I. (2009). The effect of different ratios of dory fish to tapioca flour on the linear expansion, oil absorption, colour and hardness of fish crackers. International Food Research Journal, 16, 159-165. Retrieved from

https://www.google.com/url?sa=t\& $\mathrm{rct}=\mathrm{j} \& \mathrm{q}=\& \mathrm{esrc}=\mathrm{s} \&$ source $=$ web $\& \mathrm{~cd}$ $=\&$ cad $=$ rja $\&$ uact $=8 \&$ ved $=2$ ahUKE wiy46eekJvwAhXRAnIKHfSkBN YQFjAAegQIAhAD\&url=http $\% 3$ A\%2F\%2Fwww.ifrj.upm.edu.my\% 
2F16\%2520(2)\%25202009\%2F05

$\% 2520 \mathrm{IFJ}-$

2008135\%2520Nurul\%2520Malays ia\%25202nd\%2520proof.pdf\&usg= AOvVaw3gdhnN1i7KUvA510i4a0

$3 \mathrm{~L}$.

Rahayu, W.P. (1998). Diktat penuntun praktikum penilaian organoleptik. Fakultas Teknologi Pertanian Bogor. Institut Pertanian Bogor. Bogor.

Standar Nasional Indonesia. SNI 01-43071996. Kerupuk beras. Diakses pada 12 Oktober, 2020, dari http://sispk.bsn.go.id/SNI/DaftarLis $\mathrm{t \#}$.

Sudarmadji, S., Haryono B., \& Suhardi. (1997). Analisa bahan makanan dan hasil pertanian. Yogyakarta: Liberty.

Sundari, Almasyhuri D., \& Lamid A. (2015). Pengaruh proses pemasakan terhadap komposisi zat gizi bahan pangan sumber protein. Media Penelitian dan Pengembangan Kesehatan, 25 (4), 235 - 242. DOI : 10.22435/mpk.v25i4.4590.235-242

Rosiani, N., Basito, \& Widowati E. (2015). Kajian karakteristik sensoris fisik dan kimia kerupuk fortifikasi daging lidah buaya (Aloe vera) dengan metode pemanggangan menggunakan microwave. Jurnal Teknologi Hasil Pertanian, 8 (2), 84-98. DOI: https://doi.org/10.20961/jthp.v0i0.1 2896

Winarno, F.G. (2004). Kimia pangan dan gizi. Gramedia Pustaka Utama, Jakarta. 